\title{
Inquérito civil e compromisso de
} ajustamento de conduta*

Civil investigation and commitment to conduct adjustment

José Maria Tesheiner**

Sabrina Pezzi***

\section{RESUMO}

Um estudo sobre o inquérito civil e o compromisso de ajustamento de conduta promovidos pelo Ministério Público.

\section{PALAVRAS-CHAVE}

Ministério Público - inquérito civil - compromisso de ajustamento de conduta

\footnotetext{
* Artigo recebido em 8 de maio de 2012 e aprovado em 23 de julho de 2012.

** Professor da Pontifícia Universidade Católica do Rio Grande do Sul (PUCRS), desembargador aposentado do TJRGS. Pontifícia Universidade Católica do Rio Grande do Sul, Rio Grande do Sul, Brasil. E-mail: josetesheiner@gmail.com.

*** Advogada em Porto Alegre. Especialista em direito civil e processo civil pela Faculdade IDC. Mestranda em direito pela PUCRS. Pontifícia Universidade Católica do Rio Grande do Sul, Rio Grande do Sul, Brasil. E-mail: sabripezzi@hotmail.com.
} 


\section{ABSTRACT}

An essay on the civil investigation and the commitment to conduct adjustment promoted by the Public Prosecutor.

\section{KEY-WORDS}

Public Prosecution - civil investigation - commitment to conduct adjustment

\section{Inquérito civil}

O inquérito civil é procedimento administrativo investigatório, extrajudicial, pré-processual, de competência do Ministério Público, com o objetivo de apuração de elementos de convicção para eventual propositura de ação civil pública. ${ }^{1}$

Criado pela Lei no 7.347/1985 e consagrado pela Constituição Federal de 1988 (art. 129, III²) como instrumento de tutela do patrimônio público e social, do meio ambiente e de outros interesses difusos, coletivos e individuais homogêneos, pode também ter por objeto um interesse individual, a exemplo do art. 201, inciso V, do Estatuto da Criança e do Adolescente. ${ }^{3}$

A Resolução no 23, de 17 de setembro de 2007, do Conselho Nacional do Ministério Público, "Regulamenta os artigos 60, inciso VII e 7o, inciso I, da Lei Complementar no 75/93 e os artigos 25, inciso IV e 26, inciso I, da Lei no 8.625/93, disciplinando, no âmbito do Ministério Público, a instauração e tramitação do inquérito civil".

A Resolução nº 87, do Conselho Superior do Ministério Público Federal, "Regulamenta, no âmbito do Ministério Público Federal, a instauração e tramitação do Inquérito Civil”" (art. 6o, VII, da Lei Complementar noำ 75/1993 e art. 8o, § 1ํㅡ, da Lei no $7.347 / 1985)$.

\footnotetext{
${ }^{1}$ MAZZILLI, Hugo Nigro. A defesa dos interesses difusos em juízo. São Paulo: Saraiva: 2002. p. 338. ${ }^{2}$ Art. 129. São funções institucionais do Ministério Público: (...) III - promover o inquérito civil e a ação civil pública, para a proteção do patrimônio público e social, do meio ambiente e de outros interesses difusos e coletivos.

${ }^{3}$ Compete ao Ministério Público: (...) V - promover o inquérito civil e a ação civil pública para a proteção dos interesses individuais, difusos ou coletivos relativos à infância e à adolescência, inclusive os definidos no art. 220, $§ 3^{\circ}$, inciso II, da Constituição Federal.
} 
No Rio Grande do Sul, o Provimento n² 26/2008 “Disciplina o inquérito civil e as peças de informação, incluindo a regulação do compromisso de ajustamento e da recomendação no âmbito do Ministério Público do Estado do Rio Grande do Sul".

\subsection{Características}

O inquérito civil apresenta as características da informalidade, dispensabilidade, publicidade e, duvidosamente, a da inquisitoriedade.

A informalidade apresenta-se como oposição ao rigorismo processual. ${ }^{4}$ As formas devem ser simples, mas suficientes para assegurar o adequado grau de certeza, segurança e respeito aos direitos e garantias dos envolvidos, de maneira que o conteúdo prevaleça sobre um formalismo excessivo. A mesma ideia informa a Lei no 9.784/1999, que regulamenta o processo administrativo no âmbito da administração pública federal.

Há, contudo, pressupostos mínimos, de ordem material e formal, exigidos para justificar a investigação e as providências e diligências ordenadas ${ }^{5}$.

A dispensabilidade está associada ao fato de que o inquérito civil não se apresenta como pressuposto para o ajuizamento da ação e para a celebração de compromisso de ajustamento de conduta. ${ }^{6}$ Havendo elementos suficientes para a ação, o promotor de justiça pode ou mesmo deve dispensar o inquérito, visto como procrastinatório e até mesmo descabido. ${ }^{7}$ Há dispensabilidade, inclusive possibilidade para a celebração de compromisso de ajustamento de conduta.

O inquérito civil é, de regra, público, o que não significa possa toda e qualquer pessoa, em qualquer hipótese, ter conhecimento do seu objeto e de suas particularidades. Os requerimentos para obtenção de certidões ou extração de cópia de documentos constantes nos autos sobre o inquérito civil precisam esclarecer os fins e as razões do pedido. ${ }^{8}$

\footnotetext{
${ }^{4}$ SOUZA, Motauri Ciocchetti de. Ação civil pública e inquérito civil. São Paulo: Saraiva. 2001. p. 86. ${ }^{5}$ LEONEL, Ricardo de Barros. Manual do processo coletivo. 2. ed. rev., atual. e ampl. São Paulo: Revista dos Tribunais, 2011. p. 340.

${ }^{6}$ Ibid., p. 352. Nada impediria a realização do compromisso elaborado pelo Ministério Público sem a instauração do procedimento investigatório, se com a remessa de representação ou peças de informação já dispõe o Ministério Público dos dados necessários. Se o inquérito é dispensável para a propositura da ação, com maior razão não se mostra imprescindível para a elaboração do compromisso de ajustamento. A realização do compromisso de ajustamento sem prévia investigação em inquérito civil, no entanto, só seria possível se o fato já estivesse suficientemente esclarecido.

${ }^{7}$ MAZZILLI, Hugo Nigro. O inquérito civil. São Paulo: Saraiva: 1999. p. 49.

${ }^{8}$ Resolução nº 23/2007, art. 7oㅗ $§ 5^{\circ}$.
} 
Excepcionalmente, o inquérito civil pode ser sigiloso, para preservação da intimidade do investigado, em razão da segurança do Estado ou da sociedade ou, ainda, por conveniência da instrução. $\mathrm{O}$ sigilo deve ser decretado por decisão fundamentada, podendo ser limitado a determinadas pessoas, provas, informações, dados, períodos ou fases, cessando quando extinta a causa que o motivou. ${ }^{9}$

A autoexecutoriedade vincula-se à prerrogativa que têm os membros do Ministério Público de realizar as diligências investigatórias que julgarem convenientes independentemente de autorização do Poder Judiciário. Podem requisitar documentos, exigir comparecimento sob pena de condução coercitiva, colher depoimentos, reduzir a termo compromisso de ajustamento e praticar outros atos, ainda que não expressamente previstos. ${ }^{10}$

É duvidosa a característica da inquisitoriedade, tendo em vista as garantias do contraditório e da ampla defesa outorgadas pela Constituição, inclusive nos processos administrativos (art. 5으. LV). ${ }^{11}$

Ela estaria justificada pela ausência de acusação, já que destinada tão somente à apuração de fatos e da autoria.

Alguns afirmam ser necessário o contraditório, exatamente porque não se restringe necessariamente à simples coleta de elementos da autoria e da materialidade, podendo conduzir a um compromisso de ajustamento de conduta. Ademais, o futuro réu da civil pública tem o direito constitucional de ser informado e participar ativamente do desenvolvimento procedimental do inquérito civil. Acrescentam que a observância do contraditório torna o processo da ação mais célere, por não haver necessidade de repetição de produção das provas nele produzidas, atribuindo-se-lhes considerável credibilidade.

Segundo Mazzilli, o inquérito civil pode eventualmente ter contraditório, quando conveniente ouvir os investigados, ${ }^{12}$ acrescentando que seu valor como "prova em juízo decorre de ser uma investigação pública e de caráter oficial. Quando regularmente realizado, o que nele se apurar tem validade e eficácia em juízo, como as perícias e inquirições" ${ }^{13}$

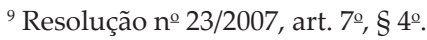

${ }^{10}$ Leonel, Manual do processo coletivo, op. cit., p. 345.

${ }^{11}$ Artigo 5o, LV - aos litigantes, em processo judicial ou administrativo, e aos acusados em geral são assegurados o contraditório e ampla defesa, com os meios e recursos a ela inerentes.

${ }^{12}$ MAZZILLI, Hugo Nigro. Questões controvertidas do inquérito civil. Revista do Ministério Público do Rio de Janeiro, n. 336.

${ }^{13}$ MAZZILLI, Hugo Nigro. O inquérito civil. São Paulo: Saraiva: 1999. p. 53.
} 
O que se conclui é que a inobservância do contraditório e da ampla defesa somente se compatibiliza com a Constituição se e enquanto não se atribuem efeitos jurídicos ao inquérito civil e às provas nele produzidas.

\subsection{Competência}

O juízo e foro competentes para a eventual ação civil pública a ser proposta determinam qual o órgão do Ministério Público competente para presidir o inquérito civil correspondente.

Pode fixar-se a competência por prevenção.

Pode ocorrer conflito de atribuições entre órgãos do Ministério Público, que é resolvido, no âmbito da mesma Instituição, pelo procurador-geral de justiça (Lei Orgânica do Ministério Público — LOMIN — art. 10, X). ${ }^{14}$

Compete ao Supremo Tribunal Federal julgar os conflitos de atribuições entre instituições diversas (Ministério Público Federal e Estadual; Ministério

Público de Estados diversos). É o que vem decidindo o Supremo Tribunal Federal, por aplicação do artigo 102, I, f, da Constituição: ${ }^{15}$

Compete ao Supremo Tribunal Federal julgar o conflito entre órgãos de Ministérios Públicos diversos, ex vi do art. 102, I, f, da Constituição (STF, Pleno, ACO 1135, Min. Ellen Gracie, relatora, j. 4/8/2011)

Admitindo o Código de Consumidor litisconsórcio facultativo entre os Ministérios Públicos da União, do Distrito Federal e dos Estados, na defesa dos interesses e dos direitos do consumidor, improcede o conflito de atribuições entre o Ministério Público Federal e o Estadual. (STF, Pleno, ACO 1020, Min. Cármen Lúcia, relatora j. 8/10/2008).

\subsection{Fases}

O inquérito civil estrutura-se em três fases, quais sejam: a instauração, a instrução e a conclusão.

\footnotetext{
${ }^{14}$ Art. 10. Compete ao Procurador-Geral de Justiça: (...) - X - dirimir conflitos de atribuições entre membros do Ministério Público, designando quem deva oficiar no feito.

${ }_{15}$ Art. 102. Compete ao Supremo Tribunal Federal, precipuamente, a guarda da Constituição, cabendo-lhe: I - processar e julgar, originariamente: $(\ldots)-\mathrm{f}$ ) as causas e os conflitos entre a União e os Estados, a União e o Distrito Federal, ou entre uns e outros, inclusive as respectivas entidades da administração indireta.
} 
A instauração pode ocorrer de ofício, por requerimento ou representação de qualquer pessoa ou autoridade, por designação do procurador-geral de justiça ou de outro órgão superior da instituição (Resolução no 23/2007 do CNMP, art. $\left.2^{\circ}\right),{ }^{16}$ com ressalva para o caso de o membro do Ministério Público ser testemunha do fato investigado. ${ }^{17}$

No caso de provocação verbal, as declarações devem ser reduzidas a termo (Resolução cit., art. 2으, $\S 2^{\circ}$ ). ${ }^{18}$

O anonimato não implica ausência de providências (Resolução cit., art. 2ํㅡ, $\left.\S 3^{\circ}\right) .{ }^{19}$

O inquérito civil é instaurado por portaria, devendo conter: o fundamento legal que autoriza a ação do Ministério Público, a descrição do fato objeto do inquérito civil, o nome e a qualificação da pessoa a quem o fato é atribuído e, se for o caso, do autor da representação, a data e local da instauração e a determinação de diligências iniciais, a designação do secretário, a determinação de afixação da portaria no local de costume, bem como a de remessa de cópia para publicação (Resolução cit., art. $4^{\circ}$ ).$^{20}$

A segunda fase do inquérito é a da instrução, em que se requisitam documentos, notificam-se as testemunhas e produzem-se as provas em direito admitidas.

\footnotetext{
${ }^{16}$ Art. $2^{2}$ - O inquérito civil poderá ser instaurado: I - de ofício; II - em face de requerimento ou representação formulada por qualquer pessoa ou comunicação de outro órgão do Ministério Público, ou qualquer autoridade, desde que forneça, por qualquer meio legalmente permitido, informações sobre o fato e seu provável autor, bem como a qualificação mínima que permita sua identificação e localização; III - por designação do Procurador-Geral de Justiça, do Conselho Superior do Ministério Público, Câmaras de Coordenação e Revisão e demais órgãos superiores da Instituição, nos casos cabíveis.

${ }^{17}$ SILVA, José Luiz Mônaco da. Inquérito civil: doutrina, legislação, modelos. São Paulo: Edipro, 2000. p. 38.

${ }^{18} \S 2$ o No caso do inciso II, em sendo as informações verbais, o Ministério Público reduzirá a termo as declarações. Da mesma forma, a falta de formalidade não implica indeferimento do pedido de instauração de inquérito civil, salvo se, desde logo, mostrar-se improcedente a notícia, atendendo-se, na hipótese, o disposto no artigo 5 desta Resolução.

$19 \S 3$ O O conhecimento por manifestação anônima, justificada, não implicará ausência de providências, desde que obedecidos os mesmos requisitos para as representações em geral, constantes no artigo 2oㅡ, inciso II, desta Resolução.

${ }^{20}$ Art. $4^{\circ} \mathrm{O}$ inquérito civil será instaurado por portaria, numerada em ordem crescente, renovada anualmente, devidamente registrada em livro próprio e autuada, contendo: I - o fundamento legal que autoriza a ação do Ministério Público e a descrição do fato objeto do inquérito civil; II o nome e a qualificação possível da pessoa jurídica e/ou física a quem o fato é atribuído; III - o nome e a qualificação possível do autor da representação, se for o caso; IV - a data e o local da instauração e a determinação de diligências iniciais; $\mathrm{V}$ - a designação do secretário, mediante termo de compromisso, quando couber; VI - a determinação de afixação da portaria no local de costume, bem como a de remessa de cópia para publicação.
} 
A recusa, o retardamento ou a omissão de dados técnicos requisitados pelo Ministério Público e indispensáveis à propositura da ação constitui crime (Lei 7.347/85, art. $10^{21}$ ).

A testemunha pode ser conduzida coercitivamente, independentemente de ordem judicial. ${ }^{22}$

Na terceira fase, que é da conclusão, determina-se o arquivamento, a celebração de compromisso de ajustamento de conduta ou a propositura de ação civil pública.

A conclusão, apresentada em um relatório, deve ocorrer no prazo de um ano, sendo permitida prorrogação por igual prazo, quantas vezes forem necessárias, por decisão fundamentada de seu presidente (Resolução no 23/2007 do CNMP, art. 9o).$^{23}$

Convencendo-se da inexistência de fundamento para a propositura de ação, o membro do Ministério Público conclui pelo arquivamento, decisão que se sujeita a reexame necessário pelo Conselho Superior do Ministério Público (no caso dos Ministérios Públicos Estaduais) ou pela Câmara de Coordenação e Revisão (no caso dos ramos do Ministério Público da União), que pode designar outro membro do Ministério Público para continuar o inquérito (Resolução no 23/2007 do CNMP, art. 10). ${ }^{24}$

\footnotetext{
${ }^{21}$ Art. 10. Constitui crime, punido com pena de reclusão de 1 (um) a 3 (três) anos, mais multa de 10 (dez) a 1.000 (mil) Obrigações Reajustáveis do Tesouro Nacional - ORTN, a recusa, o retardamento ou a omissão de dados técnicos indispensáveis à propositura da ação civil, quando requisitados pelo Ministério Público.

${ }^{22}$ Condução coercitiva de testemunha - Lei Complementar 75/1993: (Ministério Público da União) Art. 8o Para o exercício de suas atribuições, o Ministério Público da União poderá, nos procedimentos de sua competência: (...) I - notificar testemunhas e requisitar sua condução coercitiva, no caso de ausência injustificada; Lei 8.625/1993 (Ministério Público dos Estados). Art. 26. No exercício de suas funções, o Ministério Público poderá: I - instaurar inquéritos civis e outras medidas e procedimentos administrativos pertinentes e, para instruí-los: a) expedir notificações para colher depoimento ou esclarecimentos e, em caso de não comparecimento injustificado, requisitar condução coercitiva, inclusive pela Polícia Civil ou Militar, ressalvadas as prerrogativas previstas em lei.

${ }^{23}$ Art. $90-$ O inquérito civil deverá ser concluído no prazo de um ano, prorrogável pelo mesmo prazo e quantas vezes forem necessárias, por decisão fundamentada de seu presidente, à vista da imprescindibilidade da realização ou conclusão de diligências, dando-se ciência ao Conselho Superior do Ministério Público, à Câmara de Coordenação e Revisão ou à Procuradoria Federal dos Direitos do Cidadão.

${ }^{24}$ Art. 10. Esgotadas todas as possibilidades de diligências, o membro do Ministério Público, caso se convença da inexistência de fundamento para a propositura de ação civil pública, promoverá, fundamentadamente, o arquivamento do inquérito civil ou do procedimento preparatório. $\S 1^{1}$ Os autos do inquérito civil ou do procedimento preparatório, juntamente com a promoção de arquivamento, deverão ser remetidos ao órgão de revisão competente, no prazo de três dias, contado da comprovação da efetiva cientificação pessoal dos interessados, através de publicação na imprensa oficial ou da lavratura de termo de afixação de aviso no órgão do Ministério Público,
} 
$\mathrm{O}$ arquivamento não se sujeita a homologação judicial ${ }^{25}$ e não impede a propositura de ação por outro legitimado.

Também não impede a abertura de novo inquérito (Resolução no 23/2007 do CNMP, art. 12). ${ }^{26}$

\subsection{Nulidades}

A nulidade do inquérito não contamina a ação ou o compromisso de ajustamento de conduta, embora possa influir na avaliação judicial das provas nele produzidas. ${ }^{27}$

\section{Compromisso de ajustamento de conduta}

O compromisso de ajustamento de conduta previsto, pela primeira vez, no art. 211 do Estatuto da Criança e do Adolescente (Lei nº 8.069/1990), ${ }^{28}$ foi introduzido na Lei da Ação Civil Pública (Lei no 7.347/1985) pelo Código de

\footnotetext{
quando não localizados os que devem ser cientificados. § 20 A promoção de arquivamento será submetida a exame e deliberação do órgão de revisão competente, na forma do seu Regimento Interno. $\S 3^{0}$ Até a sessão do Conselho Superior do Ministério Público ou da Câmara de Coordenação e Revisão respectiva, para que seja homologada ou rejeitada a promoção de arquivamento, poderão as pessoas colegitimadas apresentar razões escritas ou documentos, que serão juntados aos autos do inquérito ou do procedimento preparatório. $§ 4^{\circ}$ Deixando o órgão de revisão competente de homologar a promoção de arquivamento, tomará uma das seguintes providências: I - converterá o julgamento em diligência para a realização de atos imprescindíveis à sua decisão, especificando-os e remetendo ao órgão competente para designar o membro do Ministério Público que irá atuar; II - deliberará pelo prosseguimento do inquérito civil ou do procedimento preparatório, indicando os fundamentos de fato e de direito de sua decisão, adotando as providências relativas à designação, em qualquer hipótese, de outro membro do Ministério Público para atuação. § 5o Será pública a sessão do órgão revisor, salvo no caso de haver sido decretado o sigilo.

${ }^{25}$ Observa Mazzilli que, ao contrário do que ocorre com o inquérito policial, no qual o Ministério Público, conquanto titular da pretensão acusatória, requer o arquivamento ao juiz, no inquérito civil não há intervenção judicial, solução mais técnica e correta, pois, sendo o inquérito mera peça informativa, a decisão de um dos legitimados ativos no sentido de não propor a ação não constitui matéria que enseje prestação jurisdicional (Mazzilli, Questões controvertidas do inquérito civil, op. cit.).

${ }^{26}$ Art. 12. O desarquivamento do inquérito civil, diante de novas provas ou para investigar fato novo relevante, poderá ocorrer no prazo máximo de seis meses após o arquivamento. Transcorrido esse lapso, será instaurado novo inquérito civil, sem prejuízo das provas já colhidas.

${ }^{27}$ Leonel, Manual do processo coletivo, op. cit., p. 345.

${ }^{28}$ Art. 211. Os órgãos públicos legitimados poderão tomar dos interessados compromisso de ajustamento de sua conduta às exigências legais, o qual terá eficácia de título executivo extrajudicial.
} 
Defesa do Consumidor (Lei nº 8.078/1990), atribuindo-lhe a eficácia de título executivo extrajudicial, ${ }^{29}$ e tendo por escopo concretizar a determinação constitucional de regulação de significativa parcela da atividade econômica, além de promover o acesso à justiça dos consumidores, ensejando uma tutela mais adequada dos direitos transindividuais. ${ }^{30}$ Anteriormente, a Lei $\mathrm{n}^{\mathrm{o}}$ 7.244/1984 já indicara o acordo extrajudicial como título executivo extrajudicial referendado pelo Ministério Público.

A Lei no 8.884/1994, que dispõe sobre a prevenção e a repressão às infrações contra a ordem econômica, disciplina o compromisso de cessação da prática investigada ou seus efeitos lesivos: compromisso de cessação de atividades $^{31}$ e compromisso de desempenho. ${ }^{32}$

\footnotetext{
${ }^{29}$ Art. 113. Acrescente-se os seguintes $\S \S 4^{\circ}$, 5o e $6^{\circ}$ ao art. $5^{\circ}$ da Lei o 7.347 , de 24 de julho de 1985: (...) § 6o Os órgãos públicos legitimados poderão tomar dos interessados compromisso de ajustamento de sua conduta às exigências legais, mediante combinações, que terá eficácia de título executivo extrajudicial". (Veja Mensagem de veto) (Veja REsp 222582 /MG-STJ).

${ }^{30}$ Segundo Nelson Neri Junior, "Há, por assim dizer, uma perfeita interação entre sistemas do CDC e da LACP, que se contempla e podem ser aplicados indistintamente às ações que versem sobre direitos ou interesses difusos, coletivos e individuais, observando o princípio da especialidade das ações sobre as relações de consumo, às quais se aplicam o Título III do CDC e só subsidiariamente a LACP. Esse interagir recíproco de ambos os sistemas (CDC e LACP) tornou-se possível em razão da adequação e perfeita compatibilidade que existe entre eles e principalmente de suas disposições finais, alterando e acrescentando artigos no texto da lei no $7.347 / 85^{\prime \prime}$. FINK, Daniel Roberto. Código Brasileiro de Defesa do Consumidor comentado pelos autores do anteprojeto. Rio de Janeiro: Forense Universitária, 2000. p. 869.

${ }^{31}$ Art. 53. Em qualquer das espécies de processo administrativo, o CADE poderá tomar do representado compromisso de cessação da prática sob investigação ou dos seus efeitos lesivos, sempre que, em juízo de conveniência e oportunidade, entender que atende aos interesses protegidos por lei. (Redação dada pela Lei $n^{\circ} 11.482$, de 2007). § $1^{\circ}$ Do termo de compromisso deverão constar os seguintes elementos: (Redação dada pela Lei no 11.482, de 2007). I - a especificação das obrigações do representado para fazer cessar a prática investigada ou seus efeitos lesivos, bem como obrigações que julgar cabíveis; (Incluído pela Lei no 11.482, de 2007). II - a fixação do valor da multa para o caso de descumprimento, total ou parcial, das obrigações compromissadas (Incluído pela Lei no 11.482 , de 2007). III - a fixação do valor da contribuição pecuniária ao Fundo de Defesa de Direitos Difusos quando cabível (Incluído pela Lei no 11.482, de 2007). § 2 o Tratando-se da investigação da prática de infração relacionada ou decorrente das condutas previstas nos incisos I, II, III ou VIII do caput do art. 21 desta Lei, entre as obrigações a que se refere o inciso I do $\S 1^{\circ}$ deste artigo figurará, necessariamente, a obrigação de recolher ao Fundo de Defesa de Direitos Difusos um valor pecuniário que não poderá ser inferior ao mínimo previsto no art. 23 desta Lei. (Redação dada pela Lei no 11.482, de 2007). § 3o A celebração do termo de compromisso poderá ser proposta até o início da sessão de julgamento do processo administrativo relativo à prática investigada. (Redação dada pela Lei oㅡ 11.482, de 2007). § 4은 termo de compromisso constitui título exclusivo extrajudicial. (Redação dada pela Lei no 11.482 , de 2007). § 5o O processo administrativo ficará suspenso enquanto estiver sendo cumprido o compromisso e será arquivado ao término do prazo fixado se atendidas todas as condições estabelecidas no termo. (Redação dada pela Lei no 11.482 , de 2007). $§ 6^{\circ} \mathrm{A}$ suspensão do processo administrativo a que se refere o $\S 5$ este artigo dar-se-á somente em relação ao representado que firmou o compromisso, seguindo o processo seu curso regular para os demais representados. (Incluído pela Lei $\mathrm{n}^{\circ}$ 11.482, de 2007). $§ 7^{70}$ Declarado o descumprimento do compromisso, o CADE
} 
Também os órgãos ambientais estão autorizados a celebrar termo de compromisso, com força de título executivo (Lei no 9.605/1998, art. 79-A). ${ }^{33}$ O artigo 876 da Consolidação das Leis do Trabalho dispõe:

Art. 876 - As decisões passadas em julgado ou das quais não tenha havido recurso com efeito suspensivo; os acordos, quando não cumpridos; os termos de ajuste de conduta firmados perante o Ministério Público do Trabalho e os termos de conciliação firmados perante as Comissões de Conciliação Prévia serão executadas pela forma estabelecida neste Capítulo. (Redação dada pela Lei no 9.958, de 12.1.2000)

O compromisso de ajustamento de conduta distingue-se da transação típica, que é celebrada por partes com capacidade para transigir e diz respeito a direitos disponíveis. É celebrado com a outra parte pelo Ministério Público ou por outro órgão público legitimado e visa à aplicação do direito objetivo.

Distingue-se dos convênios, união de esforços para o atendimento de fins públicos, que podem ou não estar relacionados a direitos transindividuais e não têm eficácia executiva.

Distingue-se da convenção coletiva de trabalho, que é celebrada entre empregados e empregadores, e da convenção coletiva de consumo, entre

aplicará as sanções nele previstas e determinará o prosseguimento do processo administrativo e as demais medidas administrativas e judiciais cabíveis para sua execução.(Incluído pela Lei n⿳o 11.482, de 2007). § $8^{\circ}$ As condições do termo de compromisso poderão ser alteradas pelo CADE se comprovar sua excessiva onerosidade para o representado, desde que a alteração não acarrete prejuízo para terceiros ou para a coletividade. (Incluído pela Lei no 11.482, de 2007). § 9o O CADE definirá, em resolução, normas complementares sobre cabimento, tempo e modo da celebração do termo de compromisso de cessação. (Incluído pela Lei oㅡ 11.482, de 2007).

${ }^{32}$ Art. 58. O Plenário do CADE definirá compromissos de desempenho para os interessados que submetam atos a exame na forma do art. 54, de modo a assegurar o cumprimento das condições estabelecidas no $\S 1$ o do referido artigo. (Vide Lei nº 9.873, de 23.11.99).§ 1 a definição dos compromissos de desempenho será levado em consideração o grau de exposição do setor à competição internacional e as alterações no nível de emprego, dentre outras circunstâncias relevantes. $\S 2^{2} \mathrm{o}$ Deverão constar dos compromissos de desempenho metas qualitativas ou quantitativas em prazos predefinidos, cujo cumprimento será acompanhado pela SDE. § $3^{\circ} \mathrm{O}$ descumprimento injustificado do compromisso de desempenho implicará a revogação da aprovação do CADE, na forma do art. 55, e a abertura de processo administrativo para adoção das medidas cabíveis.

${ }^{33}$ Art. 79-A. Para o cumprimento do disposto nesta Lei, os órgãos ambientais integrantes do SISNAMA, responsáveis pela execução de programas e projetos e pelo controle e fiscalização dos estabelecimentos e das atividades suscetíveis de degradarem a qualidade ambiental, ficam autorizados a celebrar, com força de título executivo extrajudicial, termo de compromisso com pessoas físicas ou jurídicas responsáveis pela construção, instalação, ampliação e funcionamento de estabelecimentos e atividades utilizadores de recursos ambientais, considerados efetiva ou potencialmente poluidores. (Incluído pela Medida Provisória no 2.163-41, de 23.8.2001). 
consumidores e fornecedores de produtos ou serviços, celebrada por entidades privadas, em representação de grupos em conflito.

\subsection{Natureza jurídica}

Há os que o consideram o compromisso de ajustamento espécie de transação ${ }^{34}$ e os que lhe negam essa natureza. ${ }^{35}$

A controvérsia decorre da indisponibilidade dos direitos. ${ }^{36}$ Não se trata de transação, diz Ricardo Barros Leonel, porque eventuais concessões do ente público legitimado dão espaço a atos de submissão do responsável pela lesão ao cumprimento de ordem de proteção, considerada a impossibilidade de renúncia total ou parcial do direito material. ${ }^{37}$

Diz Hugo Nigro Mazzilli:

o compromisso de ajustamento de conduta é antes um ato administrativo negocial (negócio jurídico de direito público), que consubstancia uma declaração de vontade do Poder Público coincidente com a do particular (o causador do dano, que concorda em adequar sua conduta às exigências da lei). Assim, não podem os órgãos públicos legitimados dispensar direitos ou obrigações, nem renunciar a direitos, mas devem limitar-se a tomar, do causador do dano, obrigação de fazer ou não fazer (ou seja, a obrigação de que este torne sua conduta adequada às exigências da lei). ${ }^{38}$

\footnotetext{
${ }^{34}$ Atribuem ao inquérito natureza jurídica de transação: Hugo Nigro Mazzilli, Patrícia Miranda Pizzol, Daniel Roberto Fink, entre outros.

${ }^{35}$ Negam-lhe a natureza de transação: Paulo Cezar Pinheiro Carneiro, Ricardo de Barros Leonel, entre outros.

${ }^{36}$ CARNEIRO, Paulo Cezar Pinheiro. A proteção dos direitos difusos através do compromisso de ajustamento de conduta previsto na lei que disciplina a ação civil pública. Revista da Faculdade de Direito da Universidade do Estado do Rio de Janeiro, Rio de Janeiro, v. 1, n. 1, 1993. "Na realidade, o conteúdo do compromisso de ajustamento de conduta está mais próximo do reconhecimento de uma obrigação legal a cumprir, de um dever jurídico. Não existe tecnicamente uma transação, até porque esta pressupõe concessões mútuas (artigo 1.025 CC), situação que seria impossível em sede de direitos difusos e coletivos, indisponíveis que são. O ajustamento de conduta, como a sua própria expressão gramatical revela, pressupõe necessariamente, que o terceiro não esteja cumprindo as exigências legais relativas à sua própria conduta (lato sensu) e, portanto, se compromete a fazê-lo dentro de determinado prazo, sob pena de incidência de uma cominação. A proteção dos direitos difusos através do compromisso de ajustamento de conduta previsto na lei que disciplina a ação civil pública" (p. 236).

${ }^{37}$ Leonel, Manual do Processo Coletivo, op. cit., p. 349.

${ }^{38}$ MAZZILLI, Hugo Nigro. Compromisso de ajustamento de conduta: evolução e fragilidades da atuação do Ministério Público. Revista de Direito Ambiental, v. 41, p. 93, 2006.
} 
Voltaire de Lima Moraes qualifica o compromisso de ajustamento (Lei nº 7.347/1985, art. 5o, § 6º), como transação atípica.

Diz:

Trata-se de transação atípica, considerando que a ação civil pública, esteja ela situada no plano constitucional ou no infraconstitucional, traz a marca da indisponibilidade quanto ao seu objeto material, pois os direitos que ela visa a proteger não são patrimoniais de caráter privado, caso em que ela é inadmissível (art. 84 do CC). Sendo assim, as concessões recíprocas devem situar-se, por parte do agente, v.g., tempo em que deve o infrator ajustar-se às disposições legais, ou forma de cumprimento dessas disposições, circunstâncias que levam à conclusão de que o compromisso de ajustamento constitui uma transação atípica. ${ }^{39}$

É antiga essa necessidade/dificuldade de se introduzir fenômenos novos em conceitos antigos, vinho novo em odres velhos.

A solução do autor destaca as semelhanças, sem afirmar identidade. Segue uma linha que remonta ao direito romano que introduziu, ao lado dos contratos, os quase-contratos e, ao lado dos delitos, os quase delitos.

Temos, assim, a transação típica, do Código Civil, que envolve concessões recíprocas e, ao seu lado, a transação atípica, celebrada pelo Ministério Público e outros órgãos públicos, para impor a obediência ao direito, ainda que com algumas "concessões", atinentes ao tempo e ao modo de cumprimento.

Na lição de Diogo de Figueiredo Moreira Neto, o compromisso de ajustamento de conduta é um acordo substitutivo, ato administrativo complexo, como tal regido pelo direito administrativo, que não deve ser confundido com a transação, instituto que também privilegia o consenso. ${ }^{40}$

Explica:

O acordo substitutivo, utilíssimo instituto da administração pública consensual, é um ato jurídico complexo, praticado entre Administração e administrado, ou, mesmo, com outro ente público, neste caso, em situação análoga à do administrado, com o objetivo de substituir, em

\footnotetext{
${ }^{39}$ MORAES, Voltaire de Lima. Ação civil pública: alcance e limites da atividade jurisdicional. Porto Alegre: Livraria do Advogado, 2007. p. 50-51.

${ }^{40}$ MOREIRA NETO, Diogo de Figueiredo. Curso de direito administrativo: parte introdutória, parte geral e parte especial. 15. ed. Rio de Janeiro: Forense, 2009. p. 217-8.
} 
determinada relação administrativa, uma conduta, primariamente exigível, por outra, secundariamente negociável, com a finalidade de possibilitar um melhor atendimento dos interesses públicos envolvidos. $^{41}$

Define ato administrativo complexo como:

O concurso de manifestações de vontade autônomas em que, conforme a espécie, uma delas, várias ou todas emanam da Administração Pública, tendo por objeto comum a substituição de uma relação jurídica de coordenação de vontades, tanto nas modalidades de cooperação como de colaboração, visando a um resultado de interesse público comum às partes acordantes e de competência, pelo menos, de uma delas. ${ }^{42}$

Em sentido oposto, Geisa de Assis Rodrigues afirma que o compromisso de ajustamento de conduta tem a natureza de um negócio jurídico bilateral da administração, e não a de um negócio jurídico administrativo, porque, ao celebrá-lo, não se encontra em posição de superioridade em relação ao administrado. ${ }^{43}$

A explicação do compromisso de ajustamento como um acordo substitutivo, ato administrativo complexo regido pelo direito administrativo, é a que melhor atende à natureza do ato, tendo em vista sua finalidade (aplicação do direito objetivo) e a necessária participação de um órgão do poder público.

\subsection{Legitimidade}

A legitimidade para a negociação de interesses transindividuais é por lei outorgada ao Ministério Público e a outros órgãos públicos. ${ }^{44}$

\footnotetext{
${ }^{41}$ Ibid., p. 217.

${ }^{42}$ Ibid., p. 208-9.

${ }^{43}$ RODRIGUES, Geisa de Assis. Ação civil pública e termo de ajustamento de conduta. 3. ed. Rio de Janeiro: Forense, 2011. p. 138. Disponível em: <www.bibliotecaforense.com.br>.

${ }^{44}$ Mazzilli, O inquérito civil, op. cit., p. 300 e 302. Examinando o rol dos legitimados ativos, contidos no art. 5o da Lei da Ação Civil Pública e do artigo 82 do Código de Defesa do Consumidor, podemos relacionar três categorias; a) a daqueles legitimados que, incontroversamente, podem tomar compromisso de ajustamento: Ministério Público, União, Estados, Municípios, Distrito Federal e órgãos públicos, ainda que sem personalidade jurídica, especificamente destinados à defesa de interesses difusos, coletivos e individuais homogêneos; b) a dos legitimados, que,
} 
O compromitente precisa ter capacidade para obrigar-se. Podem obrigarse entes destituídos de personalidade jurídica, públicos ou privados, como o condomínio e a massa falida.

Não é admissível composição que implique renúncia, mesmo que parcial, de direitos indisponíveis.

\subsection{Objeto}

O compromisso de ajustamento de conduta, observa Franchensein, tem por objeto a conformação às exigências da lei vigente no momento da ocorrência da ameaça ou da violação do direito transindividual. Destaca a autora que o comportamento comissivo e omissivo integrante do ajustamento é extremamente amplo, incorporando condutas já findas ou realizáveis, instantâneas e aquelas que dizem respeito a uma relação jurídica continuada. Há casos em que o compromisso é firmado para estabelecer condições temporais e até orçamentárias, como no de implementação de política pública de cuja inexistência resulte violação ou tutela inadequada de direitos transindividuais. ${ }^{45}$

Interesses transindividuais podem estar ligados ao meio ambiente, ao consumidor, à saúde, ao patrimônio histórico, à ordem econômica, à cidadania, aos direitos indígenas, à proteção dos direitos das pessoas portadoras de deficiência, à educação, aos direitos das crianças, adolescentes e idosos, dos trabalhadores e outros mais. ${ }^{46}$

Direitos individuais homogêneos também podem ser objeto de compromisso de ajustamento de conduta.

Pode ser obtida não apenas tutela específica no compromisso de ajustamento, mas também a indenização ou reparação do dano causado,

\footnotetext{
incontroversamente não podem tomar o compromisso: as associações civis, as fundações privadas, as empresas públicas e as associações de economia mista; c) a dos legitimados sobre os quais é questionável possam tomar esses compromissos, como as fundações públicas e as autarquias.

${ }^{45}$ FRANCHEISEN, Luiza. Ministério Público e políticas para a concretização da ordem social constitucional. Dissertação (mestrado em direito constitucional) - Pontifícia Universidade Católica de São Paulo, São Paulo, 1999. p. 116.

${ }^{46}$ Leonel, Manual do processo coletivo, op. cit., p. 353. Pode ser obtida não apenas tutela específica no compromisso de ajustamento, mas também a indenização ou reparação do dano causado, a constituição ou desconstituição de certa situação jurídica etc. A elaboração do compromisso de ajustamento guarda simetria com a possibilidade jurídica do pedido.
} 
a constituição ou desconstituição de certa situação jurídica, etc. A elaboração do compromisso de ajustamento guarda simetria com a possibilidade jurídica do pedido. ${ }^{47}$

Pode versar sobre cláusulas de contratos das mais variadas espécies, cláusulas abusivas ou nulas, tanto de modo preventivo como repressivo, podendo-se ajustar sua exclusão ou substituição.

Podem ser previstas medidas coercitivas para o cumprimento da obrigação ajustada.

É comum a fixação de multa diária, principalmente em casos em que o descumprimento da obrigação possa causar danos ou lesões irremediáveis, multa de caráter cominatório e não compensatório, pois seu objetivo é o cumprimento do ajustado, mediante pressão psicológica. Seu valor não deve ser irrisório nem excessivo, devendo ser levada em consideração a situação econômica do obrigado, assim como a gravidade, no caso do descumprimento. ${ }^{48}$

\subsection{Forma e conteúdo}

O compromisso de ajustamento é usualmente celebrado mediante termo, redução a escrito de declaração oral. Deve ser claro e lavrado em língua portuguesa.

Não há regra legal sobre o seu conteúdo. É recomendável que, além da identificação das partes, da descrição clara e compreensível das obrigações assumidas pelo compromitente, contenha as razões que levaram à celebração do acordo, de modo a permitir a compreensão dos motivos determinantes da solução negociada, e previsão de multa, que pode ser diária, para o caso

\footnotetext{
${ }^{47}$ Ibid., p. 353.

48 EMENTA: APELAÇÃO CÍVEL. DIREITO PÚBLICO NÃO ESPECIFICADO. EMBARGOS À EXECUÇÃO. TERMO DE AJUSTAMENTO DE CONDUTA (TAC). DANO AMBIENTAL. MULTA DIÁRIA. 1. Execução ajuizada para cobrança de multa fixada no Termo de Ajustamento de Conduta (TAC). Deliberação sentencial que reduziu a multa. 2. A multa é efetivamente exigível e sua redução atendeu ao princípio da proporcionalidade, levando em conta que não houve o inadimplemento total do acordo. 3. Vinculação da multa ao salário mínimo vedada na Constituição Federal (art. 7o, IV). 4. O Ministério Público é isento do pagamento dos encargos sucumbenciais, nos termos do art. 18 da Lei nº 7.347/85, aplicável por analogia às execuções de Termo de Ajustamento de Conduta. Ausência de má-fé do Ministério Público. APELO PROVIDO EM PARTE. (Apelação Cível no 70031983364, Primeira Câmara Cível, Tribunal de Justiça do RS, Relator: Jorge Maraschin dos Santos, Julgado em 28-10-2009).
} 
de inadimplemento. "Nada impede que as astreintes sejam cumuladas com cláusulas penais compensatórias destinadas a assegurar, ainda mais intensamente, algumas obrigações específicas" ${ }^{49}$

Observa Hugo Nigro Mazzilli: "Podem tais compromissos conter obrigações pecuniárias, mas, dados os contornos que a lei lhes deu, não devem ser estas o objeto principal do compromisso, mas sim devem ter caráter de sanção em caso de descumprimento da obrigação de comportamento assumida" ${ }^{50-51}$

O termo deve ser publicado, dele podendo ou não decorrer o arquivamento do inquérito civil.

O compromisso está sujeito ao reexame do órgão competente, como observa Hugo Nigro Mazzilli:

tendo o compromisso de ajustamento solucionado no todo ou apenas em parte algum problema afeto à investigação do Ministério Público, o órgão da instituição que o tomou deverá submeter sua manifestação fundamentada de arquivamento do respectivo inquérito civil ou das respectivas peças de informação ao colegiado competente da instituição, quer tenha sido total ou parcial o arquivamento. Esse colegiado será o Conselho Superior do Ministério Público, para os Ministérios Públicos estaduais, ${ }^{52}$ ou a competente Câmara de Coordenação e Revisão, para os ramos do Ministério Público da União. ${ }^{53-54}$

Pode submeter-se o compromisso à homologação judicial. Diz Eduardo Cambi:

Nada obsta que as partes aquiesçam na submissão do compromisso à homologação por juízo competente, o que lhe conferirá a eficácia de título executivo judicial e o sujeitará ao regime do cumprimento de

\footnotetext{
${ }^{49}$ CAMBI, Eduardo. Compromisso de ajustamento de conduta: um eficaz instrumento à disposição do Ministério Público para a implementação de políticas públicas e à efetivação dos direitos fundamentais sociais. Revista dos Tribunais, v. 908, p. 113, 2011.

${ }^{50}$ Nessa linha, o art. 17, § 1ํㅡㄹ da Lei no 8.429/1992 (Lei de Improbidade Administrativa), veda a transação em matéria de defesa do patrimônio público.

${ }^{51}$ Mazzilli, Compromisso de ajustamento de conduta, op. cit., p. 93.

${ }^{52}$ Art. 9o, Lei no 7.347/1985.

${ }^{53}$ Arts. 62, IV, e 171, IV, Lei Complementar no 75/1993.

${ }^{54}$ Mazzilli, Compromisso de ajustamento de conduta, op. cit., p. 93.
} 
sentença instituído no Código de Processo Civil, partir da alteração promovida pela Lei 11.232/2005..$^{55}$ A vantagem da homologação judicial, pela adoção do referido regime de cumprimento do título executivo (judicial), é diminuir o número de objeções e exceções invocáveis pelo compromissário inadimplente para evitar a invasão de sua esfera jurídica. ${ }^{56}$ Com isto, também se abre a possibilidade de impor a multa diretamente à pessoa do compromissário, com fundamento no art. 14, $\mathrm{V}$, parágrafo único, do CPC. ${ }^{57}$

\subsection{Anulação, rescisão, revisão e recompromisso}

O compromisso de ajustamento é anulável em casos como os de erro, dolo ou coação; ${ }^{58}$ nulo, por impossibilidade ou ilicitude do objeto, como na hipótese de concessões indevidas.

Pode ser rescindido, por impossibilidade de cumprimento decorrente de força maior ou de caso fortuito, ou pelo desaparecimento dos pressupostos que ensejaram o ajuste.

Pode ser revisto, por alteração do estado de fato (ou de direito), como no caso de se tornarem demasiadamente onerosas as medidas pactuadas, podendo as medidas nele previstas ser substituídas por outras que igualmente assegurem os interesses da coletividade.

Observa Hugo Nigro Mazzilli que, por via consensual, pode haver recompromisso, desde que advenha fato novo, ou se o causador do dano aceder em ampliar suas próprias obrigações em proveito do grupo lesado. O que não se

\footnotetext{
${ }^{55}$ MAZZILLI, Hugo Nigro. Compromisso de ajustamento de conduta: análise à luz do anteprojeto do código brasileiro de processos coletivos. In: GRINOVER, Ada Pellegrini; MENDES, Aluísio Gonçalves de Castro; WATANABE, Kazuo (Coord.). Direito processual coletivo e o anteprojeto de código brasileiro de processos coletivos. São Paulo: Ed. RT, 2007. p. 242.

${ }^{56}$ RODRIGUES, Geisa de Assis. Reflexões sobre a atuação extrajudicial do Ministério Público: inquérito civil público, compromisso de ajustamento de conduta e recomendação legal. In: CHAVES, Cristiano; ALVES, Leonardo Barreto Moreira; ROSENVALD, Nelson (Coord.). Temas atuais do Ministério Público: a atuação do Parquet nos 20 anos da Constituição Federal. 2. ed. Rio de Janeiro: Lumen Juris, 2010. p. 214-215.

${ }^{57}$ Cambi, Compromisso de ajustamento de conduta, op. cit., p. 113.

${ }^{58}$ Tendo em vista sua natureza negocial, o compromisso de ajustamento de conduta se desconstitui pelas mesmas vias com que foi feito, ou por via judicial, pelos vícios do ato jurídico em geral (Art. $171, C C / 2002$. Nesse passo, não se aplicam as limitações do art. 849 do CC/2002, porque não se trata de verdadeira e própria transação). Mazzilli, Compromisso de ajustamento de conduta, op. cit., p. 93.
} 
admite é que qualquer colegitimado público reduza ou dispense as exigências já constantes de compromisso tomado por um colegitimado. ${ }^{59}$

\subsection{Eficácia}

A eficácia do ajustamento está diretamente relacionada à sua aptidão para produzir os efeitos desejados, com destaque para a determinação da responsabilidade do obrigado pelo cumprimento do ajustado, à formação de título executivo extrajudicial, ao eventual arquivamento do inquérito civil. Supõe-se o pleno atendimento do interesse transindividual envolvido e o atendimento das exigências legais.

O artigo 9o da Lei no 7.347/1985 ${ }^{60}$ não exige homologação do Termo de Ajustamento de Conduta pelo Conselho Superior do Ministério Público, como condição de sua eficácia como título executivo extrajudicial (STJ, $1^{\text {a }}$ Turma, AgRg nos EDcl no Agravo de Instrumento n. 1.244.636, min. Teori Albino Zavascki, relator, j. 6-10-2011).

Observa Hugo Nigro Mazzilli:

A eficácia do compromisso de ajustamento inicia-se no momento em que o órgão público legitimado toma o compromisso, independentemente de qualquer outra formalidade, que a Lei Federal, aliás, não impôs. É natural, pois, que, à vista de sua estrutura consensual, possam os interessados pactuar no próprio instrumento o início, o termo, as condições ou os prazos para que seja cumprido o compromisso de ajustamento. No caso do Ministério Público, é comum que seu órgão local insira uma cláusula no instrumento, no sentido de que a obrigação

\footnotetext{
${ }^{59}$ Ibid.

${ }^{60}$ Art. 9o Se o órgão do Ministério Público, esgotadas todas as diligências, se convencer da inexistência de fundamento para a propositura da ação civil, promoverá o arquivamento dos autos do inquérito civil ou das peças informativas, fazendo-o fundamentadamente. $\S 1$ o Os autos do inquérito civil ou das peças de informação arquivadas serão remetidos, sob pena de se incorrer em falta grave, no prazo de 3 (três) dias, ao Conselho Superior do Ministério Público. § 2o Até que, em sessão do Conselho Superior do Ministério Público, seja homologada ou rejeitada a promoção de arquivamento, poderão as associações legitimadas apresentar razões escritas ou documentos, que serão juntados aos autos do inquérito ou anexados às peças de informação. § 3으 A promoção de arquivamento será submetida a exame e deliberação do Conselho Superior do Ministério Público, conforme dispuser o seu Regimento. § 4ํㅡㄹ Deixando o Conselho Superior de homologar a promoção de arquivamento, designará, desde logo, outro órgão do Ministério Público para o ajuizamento da ação.
} 
de fazer só se torne exequível se e quando o Conselho Superior do Ministério Público homologar o arquivamento do inquérito civil instaurado para apurar os fatos que ensejaram o próprio compromisso. ${ }^{61}$ Essa cláusula explica-se, pois dificilmente o causador do dano acederia em assumir perante o Promotor de Justiça local um compromisso incondicional de obrigação de fazer ou não fazer, e de plano executálo, quando soubesse que pode o Conselho Superior do Ministério Público considerar insatisfatória a solução alcançada e, em seguida, pode mandar propor a Ação Civil Pública com objeto mais abrangente. Entretanto, reitere-se, o início de eficácia do compromisso é pactuado pelos próprios contraentes, que podem ou não inserir essa cláusula. ${ }^{62-63}$

Eduardo Cambi repete essa lição:

o compromisso de ajustamento de conduta, tomado pelo Ministério Público, não tem o início de sua eficácia condicionado à homologação pelo Conselho Superior do Ministério Público (no caso dos Ministérios Públicos Estaduais) ou pelas Câmaras de Coordenação e Revisão (no caso dos ramos do Ministério Público da União), salvo se assim restar expressamente acordado. ${ }^{64}$ Significa que está apto a gerar efeitos desde sua celebração ou de outro momento indicado como termo a quo. Com efeito, o que está sujeito àqueles Órgãos Superiores da Instituição é a eventual promoção de arquivamento de inquérito civil ou de outras peças informativas ensejada pela celebração do pacto. ${ }^{65}$

A eficácia do ajuste como título executivo extrajudicial decorre do art. 585 do Código de Processo Civil, inciso II. ${ }^{66}$ Permite que o credor mova a ação de execução sem prévia sentença condenatória. Os requisitos intrínsecos, como a

\footnotetext{
${ }^{61}$ Art. 9o, Lei no $7.347 / 1985$.

${ }^{62}$ Inócua, portanto, e até inconstitucional (porque a lei local não pode dispor sobre formação de título executivo), a norma paulista que prevê que o compromisso de ajustamento tomado pelo Ministério Público só tenha eficácia a partir da homologação do arquivamento do inquérito civil pelo Conselho Superior da instituição (LC Estadual 734/93, art. 112). Nota do Autor.

${ }_{63}^{63}$ Mazzilli, Compromisso de ajustamento de conduta, op. cit., p. 93.

${ }^{64}$ Id., A defesa dos interesses difusos em juízo, op. cit., p. 105.

${ }^{65}$ Cambi, Compromisso de ajustamento de conduta, op. cit., p. 113.

${ }^{66}$ CPC - "Art. 585. São títulos executivos extrajudiciais: II - a escritura pública, ou outro documento público assinado pelo devedor e por duas testemunhas; o instrumento de transação referendado pelo Ministério Público, pela Defensoria Pública, ou pelos advogados dos transatores."
} 
certeza, liquidez e exigibilidade, previstos no art. 586 do Código de Processo Civil, ${ }^{67}$ devem estar configurados.

O compromisso tem eficácia erga omnes, impedindo ação civil pública de outro legitimado sobre a mesma matéria. Diz Hindemburgo Chateaubriand Filho:

Do ponto de vista processual, faltaria para aqueles terceiros interesse de agir, à medida que o litígio, para cuja composição estariam legitimados, teria desaparecido. $\mathrm{O}$ que reforça, de certa forma, a afirmação de que os compromissos de ajustamento de conduta não admitem concessões quanto ao interesse tutelado, senão e rigorosamente a adequada reparação do dano.

Do ponto de vista substantivo, não se quebraria igualmente o princípio segundo o qual, nas relações meramente obrigatórias, os efeitos do negócio se operam apenas entre as partes. É que as entidades legitimadas não podem, segundo a titularidade material do interesse, ser chamadas de terceiros. Elas atuam sempre como substitutos da sociedade ou de um grupo de indivíduos que, diante da impossibilidade de uma referência individualizada, não podem exercer, em nome próprio, a sua pretensão. Nesse sentido, as partes de um termo de ajustamento de conduta são sempre as mesmas, independentemente de quem, na qualidade de legitimado ativo, o tenha firmado.

O que não se pode excluir para as entidades que não tenham participado do compromisso de ajustamento de conduta é o direito de questionar a validade do negócio, numa espécie de controle indireto dos atos praticados pelos órgãos públicos legitimados. ${ }^{68}$

\section{Afirma Edis Milaré:}

O ajuizamento da ação civil pública por outro ente colegitimado, sob pena de se vulnerar o princípio da segurança jurídica, só será possível para suprir omissão da transação (por exemplo, prestação necessária,

\footnotetext{
${ }^{67} \mathrm{CPC}$ - "Art. 586. A execução para cobrança de crédito fundar-se-á sempre em título líquido, certo e exigível."

${ }^{68}$ CHATEAUBRIAND FILHO, Hindemburgo. Compromisso de ajustamento de conduta. Revista dos Tribunais, v. 781, p. 733, 2011.
} 
não incluída no compromisso) ou em razão de vício propriamente dito (por exemplo, estabelecimento de obrigações ou condições atentatórias à finalidade da lei). Em qualquer dessas situações não poderá o compromisso ser ignorado, pois a ação civil pública ou visará ao fim supletivo ou será cumulada com o pedido de desconstituição do compromisso. ${ }^{69}$

\section{Confirma Eduardo Cambi:}

O controle da adequação das condições pactuadas no compromisso de ajustamento de conduta (modo, tempo, lugar etc.) pode ser feito pelos demais colegitimados à propositura da ação civil pública, sob pena de violar o princípio da segurança jurídica. Qualquer um deles pode ajuizar a ação civil pública para suprir omissão da transação (v.g., prestação necessária, não incluída no compromisso) ou em razão de vício propriamente dito (v.g., estabelecimento de obrigações ou condições atentatórias às finalidades legais). Dessa maneira, a ação civil pública ou visará ao fim supletivo ou será cumulada com o pedido de desconstituição do compromisso. ${ }^{70}$

Em sentido contrário, a lição de Hugo Nigro Mazzilli:

A posição dos colegitimados e dos lesados é distinta: eles se beneficiam, sem dúvida, com a formação do título, mas não estão impedidos de ajuizar ações coletivas ou individuais, conforme o caso, pois não poderia um dos colegitimados pactuar com o causador do dano limitações de acesso ao Poder Judiciário, que vinculassem os lesados ou os demais colegitimados, sob pena de flagrante inconstitucionalidade. Da mesma forma, o compromisso de ajustamento não pode gerar qualquer limitação máxima de responsabilidade material do causador do dano, pois isso poderia prejudicar os verdadeiros lesados, transindividualmente considerados. Insista-se, pois, em que a única sujeição que existe para eles é a de que os colegitimados ou os próprios lesados individuais não

\footnotetext{
${ }^{69}$ MILARÉ, Edis. O compromisso de ajustamento de conduta e o Fundo de Defesa de Direitos Difusos: relação entre os instrumentos. Revista de Direito Ambiental, v. 38, p. 9, 2005.

${ }^{70}$ Cambi, Compromisso de ajustamento de conduta, op. cit., p. 113.
} 
têm interesse processual em propor ação de conhecimento para pedir a formação de um título de que já dispõem por força do compromisso já firmado. Fora do campo já coberto pelo título, porém, podem propor as ações coletivas ou individuais que entendam cabíveis. ${ }^{71}$

Diz mais:

nada impede que um órgão público legitimado tenha tomado um termo de compromisso de ajustamento com o causador do dano, e, a seguir, um outro colegitimado público, considerando insatisfatório o acordo obtido, venha a tomar, do causador do dano, um compromisso ainda mais abrangente. O que não poderá é o segundo órgão público dispensar ou diminuir a abrangência do primeiro compromisso; não se veda o contrário. ${ }^{72}$

Sem dúvida, o compromisso de ajustamento não impede a propositura de ações relativas a direitos individuais, mas, salvo nulidade, impede ação do mesmo ou de outro legitimado, com o mesmo objeto, quando relativo a interesses transindividuais. Outros legitimados não são terceiros, mas entes igualmente legitimados ao exercício de função pública.

\subsection{Prescrição e decadência}

Tendo a natureza de ato administrativo substitutivo, incidem as regras próprias do Direito Público.

Por isso, as hipóteses de nulidade são as previstas no artigo $2^{\circ}$ da Lei no 4.717/1965 (Lei da Ação Popular), submetidas ao prazo decadencial (dito de prescrição), de seu art. 21: 5 (cinco) anos.

As pretensões relativas às obrigações de fazer ou de não fazer, de entregar coisa certa ou de pagar quantia em dinheiro, assumidas pelo compromitente para com o poder público, prescrevem em cinco anos, por aplicação analógica do artigo 1o-A da Lei ํo 9.873/1999, introduzido pela Lei no 11.941/2009:

${ }^{71}$ Mazzilli, Compromisso de ajustamento de conduta, op. cit., p. 93.

${ }^{72}$ Ibid. 
Art. 1ํ-A. Constituído definitivamente o crédito não tributário, após o término regular do processo administrativo, prescreve em 5 (cinco) anos a ação de execução da administração pública federal relativa a crédito decorrente da aplicação de multa por infração à legislação em vigor.

Aplicava-se o prazo prescricional de cinco anos para as dívidas ativas do poder público, por aplicação analógica do Decreto no 20.910/1932. Afirmou-se no Recurso Especial no 1.115.078:

3. A jurisprudência desta Corte preconiza que o prazo para a cobrança da multa aplicada em virtude de infração administrativa ao meio ambiente é de cinco anos, nos termos do Decreto no 20.91032 , aplicável por isonomia por falta de regra específica para regular esse prazo prescricional.

4. Embora esteja sedimentada a orientação de que o prazo prescricional do art. 1ํo do Decreto 20.91032 - e não os do Código Civil - aplicase às relações regidas pelo Direito Público, o caso dos autos comporta exame à luz das disposições contidas na Lei 9.873, de 23 de novembro de 1999, com os acréscimos da Lei 11.941, de 27 de maio de 2009.

5. A Lei 9.873999, no art. 1ำ estabeleceu prazo de cinco anos para que a Administração Pública Federal, direta ou indireta, no exercício do Poder de Polícia, apure o cometimento de infração à legislação em vigor, prazo que deve ser contado da data da prática do ato ou, no caso de infração permanente ou continuada, do dia em que tiver cessado a infração.

6. Esse dispositivo estabeleceu, em verdade, prazo para a constituição do crédito, e não para a cobrança judicial do crédito inadimplido. Com efeito, a Lei 11.941, de 27 de maio de 2009, acrescentou o art. 1ㅇ-A à Lei 9.873,99, prevendo, expressamente, prazo de cinco anos para a cobrança do crédito decorrente de infração à legislação em vigor, a par do prazo também quinquenal previsto no art. 1ำ desta Lei para a apuração da infração e constituição do respectivo crédito.

7. Antes da Medida Provisória 1.708, de 30 de junho de 1998, posteriormente convertida na Lei 9.87399, não existia prazo decadencial para o exercício do poder de polícia por parte da Administração Pública Federal. Assim, a penalidade acaso aplicada sujeitava-se apenas ao 
prazo prescricional de cinco anos, segundo a jurisprudência desta Corte, em face da aplicação analógica do art. 1º do Decreto 20.91032.

Melhor invocar-se, agora, o já citado artigo 1o-A da Lei 9.873/1999, introduzido pela Lei nº 11.941/2009.

O prazo deve ser contado da data do inadimplemento, no caso de obrigação positiva, ou, no caso de obrigação de não fazer, da data da prática do ato.

Compromisso de ajustamento relativo a direitos individuais homogêneos interrompe o prazo prescricional das pretensões individuais (Código Civil, art. 202, VI), ${ }^{73}$ as quais se submetem às regras do Código Civil.

\subsection{Execução}

Descumprido o acordado, cabe execução, ainda que pendente ação de nulidade. Havendo mais de um obrigado, a execução pode ser proposta contra um deles ou contra todos em litisconsórcio.

Em se tratando de ajustamento de conduta relativo a direitos individuais homogêneos, cabe execução individual proposta por qualquer dos beneficiados. ${ }^{74-75}$

O descumprimento de ajuste celebrado por pessoa jurídica de direito público pode ensejar a responsabilização administrativa ou mesmo penal do agente.

\footnotetext{
${ }^{73}$ Art. 202. A interrupção da prescrição, que somente poderá ocorrer uma vez, dar-se-á: (...) VI - por qualquer ato inequívoco, ainda que extrajudicial, que importe reconhecimento do direito pelo devedor.

${ }^{74}$ PIZZOL, Patrícia Miranda. Liquidação nas ações coletivas. São Paulo: Lejus, 1998. A autora ensina: “(...) entendemos que, se a sentença condenatória proferida em ação coletiva fundada em dano a direito ou interesse difuso ou coletivo stricto sensu comporta liquidação e execução individuais por parte das vítimas ou sucessores, também o compromisso de ajustamento, quando descumprido, pode ensejar tais ações, através das quais poderão estas pessoas serem indenizadas pelos prejuízos individualmente sofridos" (p. 211).

${ }_{75}$ Mazzilli, Compromisso de ajustamento de conduta, op. cit., p. 93: "Pelas características do compromisso de ajustamento de conduta, que versa interesses transindividuais, o título por ele gerado não é constituído em favor do órgão público que o toma, mas sim em proveito de todo o grupo lesado. Portanto, pode ser executado por qualquer colegitimado ativo, bem como, caso verse interesses de objeto divisível (interesses individuais homogêneos), pode servir de título executivo para qualquer lesado individual".
} 


\section{Conclusão}

Das observações feitas no curso deste artigo, duas se destacam por sua importância teórica e prática: quanto ao inquérito civil, a de que seu dito caráter inquisitório somente se compatibiliza com a Constituição enquanto não se lhe atribuem efeitos jurídicos, assim como às provas nele produzidas; quanto ao compromisso de ajustamento, sua natureza de acordo substitutivo, ato administrativo complexo, regido pelo direito administrativo.

\section{Referências}

BRASIL. Constituição da República Federativa do Brasil. Brasília: Senado Federal, 1988.

. Lei $n^{\circ}$ 10.406, de 10 de janeiro de 2002. Institui o Código Civil. Disponível em: <www.planalto.gov.br/ccivil_03/leis/2002/110406.htm>. Acesso em: 19 jun. 2012.

. Lei $n^{0}$ 85.869, de 11 de janeiro de 1973. Institui o Código de Processo Civil. Disponível em:<www.planalto.gov.br/ccivil_03/leis/15869.htm>. Acesso em: 19 jun. 2012.

. Lei $n^{0}$ 8.078, de 11 de setembro de 1990. Dispõe sobre a proteção do consumidor e dá outras providências. Disponível em: <www.planalto.gov.br/ ccivil_03/leis/L8078.htm>. Acesso em 20 jun. 2012.

. Lei $n^{0}$ 8.069, de 13 de outubro de 1990. Dispõe sobre o Estatuto da Criança e do Adolescente e dá outras providências. Disponível em: <www.planalto. gov.br/ccivil_03/leis/18069.htm> Acesso em: 20 jun. 2012.

. Resolução no 23, de 17 de setembro de 2007. Regulamenta os artigos 6ㅜ, inciso VII, e $7^{\circ}$, inciso I, da Lei Complementar $\mathrm{n}^{\circ}$ 75/93 e os artigos 25, inciso IV, e 26, inciso I, da Lei no 8.625/93, disciplinando, no âmbito do Ministério Público, a instauração e tramitação do inquérito civil. Disponível em: <www. mp.rj.gov.br/portal/page/portal/Internet/Consulta_Juridica/Legislacao/ Resolucoes_e_Enunciados_do_CNMP/Res2023.pdf>. Acesso em: 20 jun. 2012.

. Lei $n^{0}$ 8.625, de 12 de fevereiro de 1993. Institui a Lei Orgânica Nacional do Ministério Público, dispõe sobre normas gerais para a organização do Ministério Público dos Estados e dá outras providências. Disponível em: <www.planalto.gov.br/ccivil_03/leis/18625.htm>. Acesso em: 17 jun. 2012. 
. Lei $n^{\underline{0}} 7.347$, de 24 de julho de 1985. Disciplina a ação civil pública de responsabilidade por danos causados ao meio ambiente, ao consumidor, a bens e direitos de valor artístico, estético, histórico, turístico e paisagístico (VETADO) e dá outras providências. Disponível em: <www.planalto.gov.br/ ccivil_03/leis/17347orig.htm>. Acesso em: 24 jun. 2012.

. Lei Complementar nํ75, de 20 de maio de 1993. Dispõe sobre a organização, as atribuições e o estatuto do Ministério Público da União. Disponível em: <www.planalto.gov.br/ccivil_03/leis/lcp/Lcp75.htm>. Acesso em: 23 jun. 2012.

. Lei $n^{\underline{0}}$ 8.884, de 11 de julho de 1994. Transforma o Conselho Administrativo de Defesa Econômica (CADE) em Autarquia, dispõe sobre a prevenção e a repressão às infrações contra a ordem econômica e dá outras providências. Disponível em: <www.planalto.gov.br/ccivil_03/leis/18884.htm>. Acesso em: 17 jun. 2012.

. Lei $n^{0}$ 9.605, de 12 de fevereiro de 1998. Dispõe sobre as sanções penais e administrativas derivadas de condutas e atividades lesivas ao meio ambiente, e dá outras providências. Disponível em: <www.planalto.gov.br/ccivil_03/ leis/19605.htm>. Acesso em: 22 jun. 2012.

. Lei $n^{\circ}$ 8.429, de 2 de junho de 1992. Dispõe sobre as sanções aplicáveis aos agentes públicos nos casos de enriquecimento ilícito no exercício de mandato, cargo, emprego ou função na administração pública direta, indireta ou fundacional e dá outras providências. Disponível em: <www.planalto.gov. br/ccivil_03/leis/18429.htm>. Acesso em: 22 jun. 2012.

. Lei $n^{\underline{o}}$ 8.429, de 2 de junho de 1992. Dispõe sobre as sanções aplicáveis aos agentes públicos nos casos de enriquecimento ilícito no exercício de mandato, cargo, emprego ou função na administração pública direta, indireta ou fundacional e dá outras providências. Disponível em: <www.planalto.gov. br/ccivil_03/leis/18429.htm>. Acesso em: 22 jun. 2012.

- Tribunal de Justiça do Estado do Rio Grande do Sul. Apelação Cível $n^{0}$ 70031983364. Relator: Jorge Maraschin dos Santos. Disponível em: <www. tjrs.jus.br/busca/?q=70031983364\&tb=jurisnova\&pesq=ementario\&partialfiel ds=tribunal\%3ATribunal\%2520de \%2520Justi\%25C3\%25A7a\%2520do\%2520R S.\%28TipoDecisao\%3Aac\%25C3\%25B3rd\%25C3\%25A3o\%7CTipoDecisao \%3 Amonocr\%25C3\%25A1tica\%7CTipoDecisao\%3Anull\%29\&requiredfields=\& as_q=>. Acesso em 22 jun. 2012. 
CAMBI, Eduardo. Compromisso de ajustamento de conduta: um eficaz instrumento à disposição do Ministério Público para a implementação de políticas públicas e à efetivação dos direitos fundamentais sociais. Revista dos Tribunais, v. 908, 2011.

CARNEIRO, Paulo Cezar Pinheiro. A proteção dos direitos difusos através do compromisso de ajustamento de conduta previsto na lei que disciplina a ação civil pública (lf-7347 de 1985 - art-5 par-6). Revista da Faculdade de Direito da Universidade do Estado do Rio de Janeiro, Rio de Janeiro, v. 1, n. 1, 1993.

CHATEAUBRIAND FILHO, Hindemburgo. Compromisso de ajustamento de conduta. Revista dos Tribunais, v. 781, 2011.

FINK, Daniel Roberto. Código Brasileiro de Defesa do Consumidor comentado pelos autores do anteprojeto. Rio de Janeiro: Forense Universitária, 2000.

FRANCHEISEN, Luiza. Ministério Público e políticas para a concretização da ordem social constitucional. Dissertação (mestrado em direito constitucional) Pontifícia Universidade Católica de São Paulo, São Paulo, 1999.

LEONEL, Ricardo de Barros. Manual do processo coletivo. 2. ed. rev., atual. e ampl. São Paulo: Revista dos Tribunais, 2011.

MAZZILLI, Hugo Nigro. A defesa dos interesses difusos em juízo. 13. ed. São Paulo: Saraiva, 2001.

. O inquérito civil. São Paulo: Saraiva: 1999.

. Questões controvertidas do inquérito civil. Revista do Ministério Público do Rio de Janeiro, n. 336.

. Compromisso de ajustamento de conduta: evolução e fragilidades da atuação do Ministério Público. Revista de Direito Ambiental, v. 41, 2006.

. Compromisso de ajustamento de conduta: análise à luz do anteprojeto do código brasileiro de processos coletivos. In: GRINOVER, Ada Pellegrini; MENDES, Aluísio Gonçalves de Castro; WATANABE, Kazuo (Coord.). Direito processual coletivo e o anteprojeto de código brasileiro de processos coletivos. São Paulo: Ed. RT, 2007.

MILARÉ, Edis. O compromisso de ajustamento de conduta e o Fundo de Defesa de Direitos Difusos: relação entre os instrumentos. Revista de Direito Ambiental, v. 38, 2005. 
MORAES, Voltaire de Lima. Ação civil pública: alcance e limites da atividade jurisdicional. Porto Alegre: Livraria do Advogado, 2007.

MOREIRA NETO, Diogo de Figueiredo. Curso de direito administrativo: parte introdutória, parte geral e parte especial. 15. ed. Rio de Janeiro: Forense, 2009. PIZZOL, Patrícia Miranda. Liquidação nas ações coletivas. São Paulo: Lejus, 1998. RODRIGUES, Geisa de Assis. Ação civil pública e termo de ajustamento de conduta. 3. ed. Rio de Janeiro: Forense, 2011. Disponível em: <www.bibliotecaforense. com.br>.

. Reflexões sobre a atuação extrajudicial do Ministério Público: inquérito civil público, compromisso de ajustamento de conduta e recomendação legal. In: CHAVES, Cristiano; ALVES, Leonardo Barreto Moreira; ROSENVALD, Nelson (Coord.). Temas atuais do Ministério Público: a atuação do Parquet nos 20 anos da Constituição Federal. 2. ed. Rio de Janeiro: Lumen Juris, 2010.

SILVA, José Luiz Mônaco da. Inquérito civil: doutrina, legislação, modelos. São Paulo: Edipro, 2000.

SOUZA, Motauri Ciocchetti de. Ação civil pública e inquérito civil. São Paulo: Saraiva, 2001. 